\title{
Pengelolaan timbulan sampah rumah tangga oleh Bumdes Kalurahan Sendangtirto Kapenawon Berbah Kabupaten Sleman
}

\author{
Radjali Amin ${ }^{1, *}$, Nur Iswanto ${ }^{2}$, Dewi Eviane ${ }^{2}$, Iim Imaniah ${ }^{2}$, Jumiati $^{3}$ \\ ${ }^{1}$ Program Studi Ilmu Lingkungan, Sekolah Pascasarjana, Institut Teknologi Yogyakarta, Indonesia \\ ${ }^{2}$ Program Studi Teknik Lingkungan, Sekolah Pascasarjana, Institut Teknologi Yogyakarta, Indonesia \\ ${ }^{3}$ Fakultas Teknik Lingkungan, Institut Teknologi Yogyakarta, Indonesia \\ Email: *r.amin@ity.ac.id
}

Received May 5, 2021; Revised May 23, 2021; Accepted May 24, 2021

\begin{abstract}
Every household produces waste and the waste problem is increasing in line with the human population. Therefore, every family must understand how to process the waste at the first stage correctly so the residues can be reduced. The small amount of the residues may not put burden in the waste Final Processing Site. The purpose of this study was to calculate waste production of members of the villagers enterprise body (Bumdes) of Sendangtirto Village, Berbah, Sleman, DIY. This study would evaluate the waste management and provide strategies to improve the Bumdes efficiency. The research method was conducted by visiting waste processing site, interviewing selected respondents, SWOT test and evaluating the results descriptive qualitatively. It was recognized that the respondents did not segregate their waste, there was a high potential for waste management through $3 R$ program, and predominantly of the respondents agreed to carry out waste segregation at the first stage.
\end{abstract}

Keywords: Segregation; 3R; Household Waste

\begin{abstract}
Abstrak
Sampah rumah tangga tidak bisa dihindari dan bahwa masalahnya semakin meningkat sejalan dengan penambahan populasi manusia adalah keniscayaan. Oleh sebab itu, setiap keluarga wajib mengetahui pengelolaan sampah di tingkat penghasil dengan tepat sehingga residu sampah dapat ditekan yang pada akhirnya tidak terlalu membenani Tempat Pemrosesan Akhir sampah. Tujuan penelitian ini adalah menghitung timbulan sampah rumah tangga di kelompok anggota Badan Usaha Desa (Bumdes) Kalurahan Sendangtirto, Kapenawon Berbah, Kabupaten Sleman, Daerah Istimewa Yogyakarta. Selain itu, studi ini juga akan mengevaluasi pengelolaan timbulan itu serta memberikan strategi peningkatan efisiensi pengelolaan sampah oleh Bumdes. Metode penelitian dilakukan dengan cara mengunjungi tempat pengolahan sampah, mewawancarai responden yang ditentukan secara purposive sampling, melakukan SWOT test dan evaluasinya secara deskriptif kualitatif. Secara umum diakui bahwa para responden tidak memilah sampahnya, terdapat potensi yang tinggi pengelolaan sampah melalui program 3R, dan sebagain besar responden setuju untuk melaksanakan pemilahan sampah.
\end{abstract}

Kata Kunci : Pemilahan sampah; 3R; Sampah Rumah Tangga

\section{PENDAHULUAN}

Sampah Rumah Tangga (SRT) adalah barang atau benda yang keberadaannya di dalam rumah selalu ditolak walaupun setiap hari dihasilkan, sehingga secepat mungkin SRT dikeluarkan dari rumah. Adalah wajar jika SRT ini ingin segera dikeluarkan dari rumah karena berbau tidak sedap dan menjadi sumber penyakit. Setelah berada di luar rumah maka akan dikumpulkan oleh petugas sampah dan diangkut ke lokasi pengolahan. Hal serupa juga terjadi di sebagian besar kota-kota besar di Indonesia termasuk di Kalurahan Sendangtirto, Kapenawon Berbah, Kabupaten Sleman, Daerah Istimewa Yogyakarta (DIY). Populasi sampah rumah tangga terus meningkat setiap tahunnya yang sejalan dengan pertambahan populasi dan kemajuan teknologi yang berujung pada pergeseran gaya hidup seseorang terhadap SRT; padahal di lain pihak luas lahan yang diperuntukkan bagi pengoperasian tempat pemrosesan akhir (TPA) dan tempat penampungan sementara (TPS) tidak berkembang secara signifikan sehingga kondisi TPA atau TPS yang "muntah" sering kita temukan, misalnya TPA Piyungan, Kabupaten Bantul, DIY yang menjadi tujuan utama pembuangan sampah rumah tangga masyarakat Yogyakarta dan sekitarnya. 
Dari segi regulasi, pengaturan pengoperasian TPA dan TPS telah dikeluarkan oleh Kementerian Pekerjaan Umum (PU) melalui Peraturan Menteri (Permen) PU nomor 03 tahun 2013 tahun tentang Penyelenggaraan Prasarana Dan Sarana Persampahan Dalam Penanganan Sampah Rumah Tangga Dan Sampah Sejenis Sampah Rumah Tangga yang mengatur bagaimana SRT dikelola dengan baik di TPA dan TPS agar tidak "muntah" dan memberikan nilai tambah kepada pengelola tanpa mencemari lingkungan. Permasalahan SRT ini juga telah menarik perhatian pemerintah pusat sehingga Presiden RI mengeluarkan seruan pengurangan SRT melalui beberapa target dan pencapaian yang dituangkan di dalam Peraturan Presiden (Perpres) nomor 97 tahun 2017 tentang Kebijakan Dan Strategi Nasional Pengelolaan Sampah Rumah Tangga Dan Sampah Sejenis Sampah Rumah Tangga. Dalam skala nasional, SRT ditargetkan untuk dapat dikurang 14 juta ton (22\%) pada tahun 2020 dan sebesar 16,4 juta ton (24\%) pada tahun 2021, sementara itu timbulan sampah setiap tahunnya yang dicatat dalam tahun 2019 adalah sebesar 64 juta ton [1].

Upaya pengurangan SRT ini tidak dapat dilaksanakan oleh pemerintah saja dengan tanpa melibatkan peran masyarakat di lapisan paling bawah sebagai penghasil SRT [2]. Tuntunan pengelolaan sampah di Kabupaten Sleman telah dikeluarkan dan diatur oleh Peraturan Daerah (Perda) nomor 04 tahun 2015 tentang Pengelolaan Sampah Rumah Tangga Dan Sampah Sejenis Sampah Rumah Tangga. Salah satu aspek pengelolaan sampah yang diatur di dalam Perda ini adalah kegiatan pemilahan sampah yang secara khusus dibahas di dalam Pasal 15 sampai Pasal 17. Diharapkan dengan pemilahan SRT maka volume sampah yang menjadi residu dan dikirim ke TPS dan TPA berkurang sehingga target pengurangan SRT skala nasional dapat tercapai. Faktanya, transferstation yang dikelola oleh Bumdes Sendangtirto, Kapenawon Berbah kewalahan menangani SRT ini karena pemilahan yang diharapkan dilaksanakan di tingkat penghasil ternyata tidak terjadi.

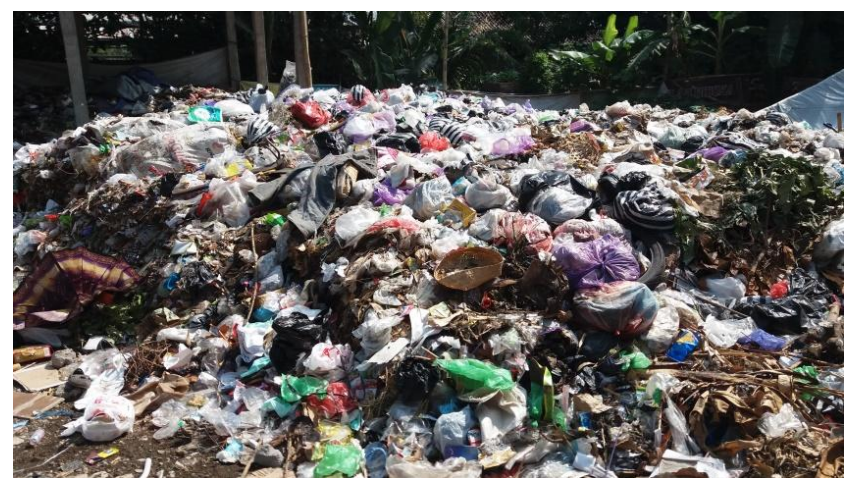

Gambar 1. Tumpukan SRT di Transferstation Bumdes Sendangtirto, Kabupaten Sleman

Gambar 1 menunjukkan timbunan SRT yang menggunung karena tidak sempat dikelola oleh petugas Bumdes. Ini terutama disebabkan oleh pemilahan yang tidak dilakukan pada tahap awal, hal ini terlihat dari tercampurnya berbagai jenis SRT di dalam kantong-kantong plastik kresek. Dalam kaitan dengan itu maka perlu diketahui lebih dalam alasan pemilahan yang tidak terjadi, seberapa banyak timbulan SRT yang dikelola dan evaluasi pengelolaan timbulan sampah oleh Bumdes agar dapat diberikan strategi dalam upaya peningkatan efisiensi pengelolaan sampah sehingga permasalahan ini dapat diselesaikan dengan baik.

Idealnya, sampah yang dikirim ke TPA adalah sampah yang telah dikelola dari bagian hulunya, baik oleh penghasil atau pengelola di TPS atau di transferstation, sehingga yang lolos dari sini benar-benar sudah berupa residu dengan nilai ekonomi yang (sangat) kecil. Kenyataannya, pengelolaan di bagian "hulu dan tengah" jarang terjadi atau bahkan tidak terjadi (Gambar 2).

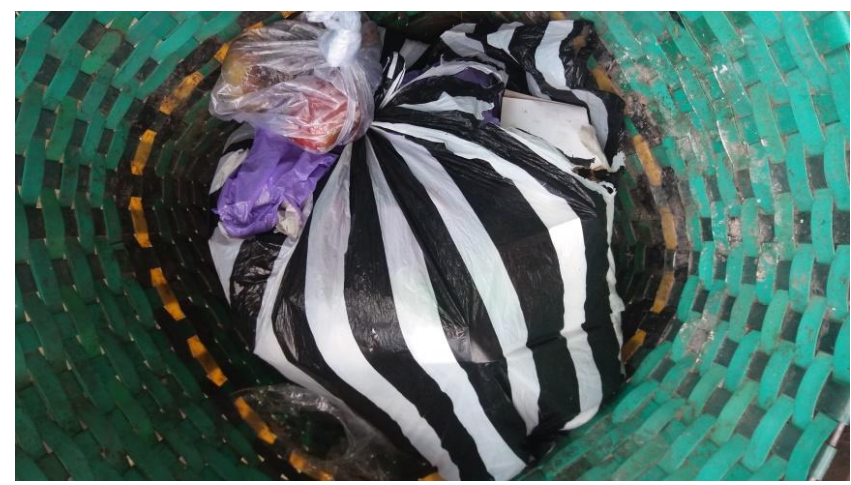

Gambar 2. Kondisi SRT di Dalam Keranjang Sampah Yang Siap Dikumpulkan Oleh Petugas Sampah, Tidak Terpilah dengan Baik 
Data KLHK yang dikutip oleh Baqiroh [1] menunjukkan bahwa sampah bahan organik seperti sisa makanan dan tumbuhan, yang seharusnya dapat dimanfaatkan jika pemilahan terjadi, mendominasi hingga $50 \%$ dari komposisi sampah. Dengan rendahnya pemilahan sampah organik maka dapat dipastikan bahwa SRT berbau tidak sedap, produksi atau pemanfaatan bahan ini sebagai kompos di rumah tangga tidak terjadi. Di lain pihak, ironisnya sering kompos dibeli untuk pupuk tanaman di rumah tangga. Bau tidak sedap yang dikeluarkan oleh SRT berasal dari proses peruraian bahan organik terutama protein oleh jamur dan bakteri atau mikroorganisma menjadi amoniak dan senyawa lain yang berbau tidak sedap bagi kita.

Menurut regulasi di bidang pengelolaan SRT, Peraturan Pemerintah (PP) Republik Indonesia nomor 81 tahun 2012 tentang Pengelolaan Sampah Rumah Tangga Dan Sampah Sejenis Sampah Rumah Tangga dijelaskan bahwa pemilahan SRT atau segregasi adalah upaya pengelompokkan SRT menurut jenis-jenisnya. Pemilahan SRT akan memberikan dampak yang besar jika dilakukan langsung oleh penghasil dan adalah salah satu upaya untuk dapat mengurangi problem pengelolaan SRT [2-3]. Pemilahan SRT juga dipandang sebagai langkah awal pemanfaatan dan pengurangan SRT yang berhasil. Beberapa hasil pengamatan dan penelitian keberhasilan pemilahan SRT disajikan di dalam Tabel 1.

Tabel 1. Pengurangan SRT Karena Keberhasilan Pemilahan di Tahap Awal/Penghasil

\begin{tabular}{lcl}
\hline & Lokasi & \multicolumn{1}{c}{ Keterangan } \\
\hline Nasional & $7,2 \%$ & Data dari KLHK [4] \\
Semarang & $20 \%$ & Data dari Undip dan Yayasan Bintari [5] \\
Surabaya & $33 \%$ & {$[6]$} \\
Desa Kaba-Kaba, Tabanan & $25 \%-30 \%-$ & {$[7]$} \\
Kecamatan Kiaracondong, Bandung & $8,82 \%$ & Hanya sampah anorganik/plastik [8] \\
\hline
\end{tabular}

Sesuai dengan namanya, SRT berasal dari rumah tangga dan SRT ini penting untuk dikelola dengan baik karena total sampah yang masuk ke TPA sebesar $48 \%$ berasal dari rumah tangga [1]. Sumber sampah sampah lain, seperti sampah industri sebagian besar berupa sampah anorganik yang biasanya sudah ada pengelola sendiri yang bersifat komersial dan limbah bahan beracun dan berbahaya (B3) yang pengelolaannya telah diatur di dalam PP nomor 22 tahun 2021 tentang Penyelenggaraan Perlindungan dan Pengelolaan Lingkungan Hidup yang pada prinsipnya melarang pembuangan limbah B3 yang dibuang/dikirim ke TPA sehingga tidak membebani TPA atau dengan kata lain, limbah B3 harus dikelola dengan baik secara khusus.

Strategi yang diberikan dalam upaya peningkatan efisiensi pengelolaan sampah oleh Bumdes akan memberikan manfaat berupa berkurangnya jumlah timbulan sampah yang dihasilkan; sebagai bentuk keberhasilan pengelolaan SRT yang sesuai dengan regulasi Perpres nomor 97 tahun 2017 dan Perda nomor 04 tahun 2015.

\section{METODE}

Metode pengumpulan data adalah dengan wawancara menggunakan daftar pertanyaan yang termodifikasi. Sampel dikumpulkan secara purposive total sampling yang diambil dari sebagian dari populasi pelanggan jasa pemungutan sampah Bumbes, yaitu di RT04/RW38 Dusun Noyokerten, Kalurahan Sendangtirto, Kapenawon Berbah, Kabupaten Sleman. Sebagian sampel yang tidak terambil adalah mereka yang ketika pelaksanaan sampling mereka tidak ada di tempat. Dengan kata lain, penentuan sampel berbasarkan ketersediaan waktu/kesempatan dari anggota populasi yang berjumlah 27 kepala keluarga (KK). Survey dilaksanakan pada tanggal 15 dan 22 November 2020 yang didampingi oleh salah satu pengurus Bumdes Sendangtirto.

Untuk mengidentifkasi strategi Pengelolaan Timbulan Sampah Rumah Tangga Oleh Bumdes Kalurahan Sendangtirto, Kapenawon Berbah, Kabupaten Sleman digunakan analisis Strength, Weakness, Opportunity, dan Threat (SWOT). Analisis SWOT terdiri dari analisis internal dan eksternal, untuk menentukan dan menganalisa strategi yang dimaksud. Analisis internal bertujuan untuk mengidentifikasi dan menjelaskan berbagai faktor yang menjadi kekuatan (strength) dan kelemahan (weakness), kajian internal pada hakekatnya merupakan analisis dan evaluasi atas kondisi, kinerja dan permasalahan yang dihadapi dalam pelaksanaan strategi sektor sanitasi. Sedangkan analisis eksternal bertujuan untuk mengidentifikasi dan menjelaskan berbagai faktor yang menjadi kesempatan/peluang (opportunity) dan tantangan/ ancaman (threat) [9]. Evaluasi hasil dilaksanakan secara deskriptif kualitatif dengan mengacu kepada hasil - hasil survey.

\section{HASIL DAN PEMBAHASAN}

Dari data pelanggan pengelolaan sampah rumah tangga (SRT) Bumdes Sendangtirto, jumlah pelanggan di RT04/RW38 Dusun Noyokerten sebanyak 27 KK. Jadi jumlah itu, sebanyak 19 KK (70,4\%) telah disurvey 
dengan hasil seperti di dalam Tabel 2. Sisanya sebesar $8 \mathrm{KK}$ tidak diwawancarai karena tidak dapat diwawancarai/ditemui. Kedelapan orang ini sedang bekerja ketika studi sedang berlangsung.

Tabel 2. Hasil Survey Penghasil Sampah di RT04/RW 38, Dusun Noyokerten yang Dilayani Oleh Bumdes Sendangtirto

\begin{tabular}{lrl}
\hline \multicolumn{1}{c}{ Parameter } & Hasil Sampel & \multicolumn{1}{c}{ Keterangan } \\
\hline Jumlah responden & $19 \mathrm{KK}$ & Sebesar 70,4\% dari total 27 KK \\
Jumlah orang yang dikelola & 69 orang & \\
Jumlah bayi/anak kecil pakai pempers & 4 anak & Sudah termasuk di dalam 69 orang sampel \\
\hline
\end{tabular}

Hasil wawancara dengan para reponsen diketahui bahwa jumlah orang yang terlibat di dalam studi adalah 69 orang dan 4 orang anak yang masih memakai pempers. Informasi jumlah anak menggunakan pampers perlu didata mengingat pempers memegang peranan yang penting di dalam SRT [10] karena pempers tidak mudah terurai dan jumlahnya semakin meningkat sejalan dengan meningkatnya populasi manusia. Dampaknya, terutama dalam nilai estetika, tidak bagus karena sifatnya yang mengapung di permukaan air sehingga mudah terlihat, menghalangi sinar matahari masuk ke dalam air dan dapat menyebabkan saluran terhambut.

\subsection{Volume SRT}

Perhitungan timbulan sampah seharusnya dihitung atau ditimbang secara langsung di lapangan namun ini tidak dilakukan sehingga untuk mengetahuinya digunakan beberapa standar yang berlaku di Indonesia hingga standar yang diterapkan di Kabupaten Sleman untuk tiap orang atau kepala seperti yang disajikan di dalam Tabel 3. Dari sini, kemudian dihitung rata-ratanya dan menjadi timbulan SRT empirik.

Tabel 3. Perhitungan Perkiraan Timbulan SRT di RT04/RW38 Dusun Noyokerten Berdasarkan Beberapa Standar

\begin{tabular}{|c|c|c|c|c|}
\hline Nama Standar & $\begin{array}{c}\text { Standar } \\
\text { (/hari/kepala) }\end{array}$ & SRT Sampel & Total SRT & Keterangan \\
\hline KLHK & $0,7 \mathrm{~kg}$ & $48,3 \mathrm{~kg}$ & $68,6 \mathrm{~kg}$ & {$[1]$} \\
\hline Pekerjaan & $2,5 \mathrm{~L}$ & $27,1 \mathrm{~kg}$ & $38,6 \mathrm{~kg}$ & Densitas sampah $=0,15739 \mathrm{~kg} / \mathrm{L}$ \\
\hline $\begin{array}{l}\text { SNI 19-3964- } \\
1994\end{array}$ & $0,486 \mathrm{~kg}$ & $33,6 \mathrm{~kg}$ & $47,3 \mathrm{~kg}$ & Standar kawasan perkampungan \\
\hline Kab. Sleman & $0,8 \mathrm{~kg}$ & $55,2 \mathrm{~kg}$ & $78,4 \mathrm{~kg}$ & {$[4]$} \\
\hline Kota Semarang & $3,3 \mathrm{~L}$ & $36,8 \mathrm{~kg}$ & $52,3 \mathrm{~kg}$ & Densitas sampah $=0,15739 \mathrm{~kg} / \mathrm{L}$ \\
\hline Rata-rata & $0,58 \mathrm{~kg}(\delta \pm 0,16)$ & $\begin{array}{c}40,2 \mathrm{~kg} \\
(\delta+11,4)\end{array}$ & $\begin{array}{c}57,1 \mathrm{~kg} \\
(\delta+16,2)\end{array}$ & \\
\hline
\end{tabular}

Untuk RT04/RW38 Dusun Noyokerten produksi SRT seharinya adalah $57,1 \mathrm{~kg}(\delta \pm 16,2)$ atau sekitar $0,36 \mathrm{~m}^{3} /$ hari untuk $22 \mathrm{KK}$ atau sekitar $0,02 \mathrm{~m}^{3} / \mathrm{KK} /$ hari dan jika disaumsikan satu keluarga terdiri dari 2 orang dewasa dan 2 anak, maka setiap orang menghasilkan 0,004-0,005 mºrang/hari. Dari segi berat, sekitar 0,8 $\mathrm{kg}$ /orang/hari. SRT ini jika tidak dikelola dengan baik maka akan terakumulasi dan menimbulkan permasalahan.

\subsection{Pemilahan Sampah}

SRT ini dapat dibilang seluruhnya masih tercampur, hanya $26 \%$ responden saja yang melakukan pemilahan sampah, terutama mereka yang mempunyai binatang piaraan seperti ayam dan kucing sementara sisanya tidak melakukan pemilahan. Pemiliahan yang dilakukan oleh pemilik binatang piaraan ini adalah dengan mengambil sisa sampah dapur dan meja makan untuk pakan binatangnya.

Selain untuk pakan, pemilahan juga dilakukan untuk memanfaatkan kardus bekas dan kantong plastik kresek untuk wadah belanjaan bagi mereka yang punya toko. Ada pula yang telah memanfaatkan sisa dapur sebagai pupuk tanaman. 


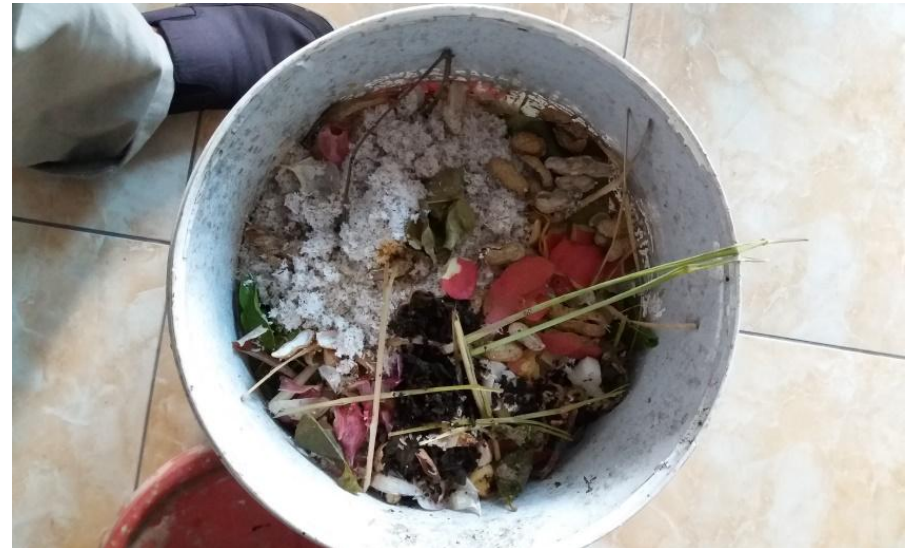

Gambar 3. Ember Bekas Cat Yang Berisi Sampah Organik dari Dapur Hasil Pemilahan

Alasan utama mereka tidak melakukan pemilahan sampah adalah males atau ribet (62\%), sebagian kecil merasa bahwa SRT terlalu sedikit untuk dipilah (25\%), sedangkan selebihnya ada yang tidak tahu kalau harus dipilah dan sengaja tidak dipilah untuk memberikan penghasilan tambahan bagi yang memungut SRT. Namun untuk semangat pemilahan, hampir $80 \%$ reponden merasa setuju dan mau kalau diminta untuk memilah sampah. Hasil observasi selama survey, diketahui bahwa sesungguhnya seluruh responden telah melakukan pemilahan dan 3R namun dalam bentuk yang sangat sederhana. Seluruh responden menggunakan kantong plastik kresek bekas, yang mereka dapatkan dari belanja, untuk mewadahi SRT. Ini artinya, mereka telah merasakan manfaat dari upaya pemilahan. Proses pembelajaran lanjutan yang lebih memberikan arti dan manfaat pemilahan SRT dan hasil pilahanannya diharapkan dapat memberikan motivasi bagi mereka untuk lebih meningkatkan upaya pemilahan dan $3 R$.

RT04/RW38 termasuk perkampungan yang padat dan berada di antara sawah dan kolam ikan yang dikelola oleh masyarat. Kepadatan perumahan ini memberikan kesempatan yang kurang leluasa bagi pemiliknya untuk memiliki lahan pekarangan yang luas. Hanya 4 KK (14,8\%) saja yang memiliki lahan yang dapat dimanfaatkan.

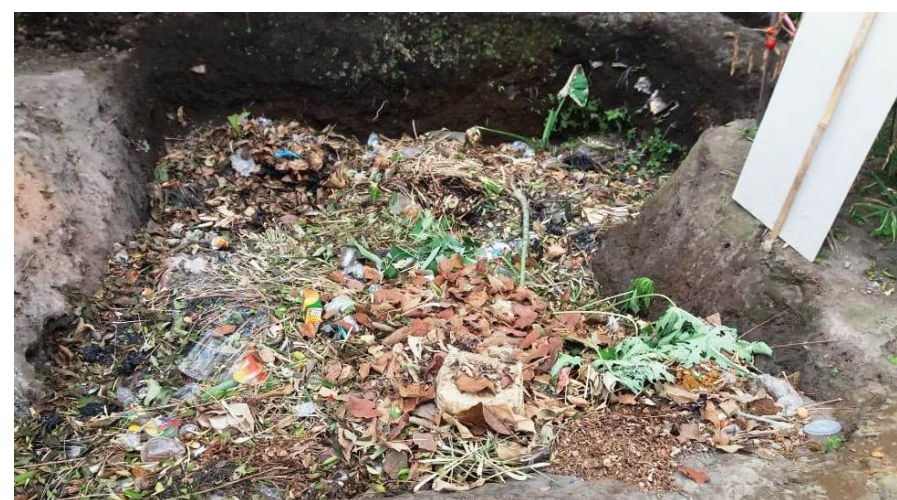

Gambar 4. Jogangan di Lahan Pekarangan Salah Seorang Responden Yang Diisi Dengan Sampah Organik

Jogangan berupa lubang di dalam tanah yang dimanfaatkan untuk membuang sampah dapur yang sebagian besar adalah sampah organik. Karena posisinya terbuka di pekarangan, maka jogangan juga berfungsi sebagai tempat peresapan air hujan juga [13]. Dengan demikian, maka pembuangan sampah ke dalam jogangan harus tidak mengandung bahan-bahan beracun dan berbahaya yang dapat mengkontaminasi air tanah. Setelah penuh, jogangan ditutup lagi dengan tanah dan pemilik rumah akan menggali jogangan baru untuk menempatkan sampah lagi.

\subsection{Potensi Keberhasilan Pemilahan SRT}

Berdasarkan Badan Pusat Statistik, pengelompokkan usia produktif adalah 15 - 64 tahun dan tidak produktif adalah > 64 tahun. Dari data yang dikumpulkan, kelas umur para responden seperti di dalam

Tabel 4. 
Tabel 4. Distribusi Kelas Umur Para Responden

\begin{tabular}{ccc}
\hline \multirow{2}{*}{ Responden } & \multicolumn{2}{c}{ Kelas Umur } \\
\cline { 2 - 3 } & $15-64$ tahun & $>64$ tahun \\
\hline Jumlah (orang) & 17 & 2 \\
\hline
\end{tabular}

Jika salah satu keberhasilan pemilahan SRT adalah kelas usia, dengan asumsi kelas usia produktif adalah mereka yang masih mempunyai semangat untuk mengerjakan hal-hal baru, maka dapat dikatakan bahwa keberhasilan pemilahan ini cukup tinggi (89,5\%). Dua responden yang termasuk di dalam kelas tidak produktif tidak melakukan pemilahan SRT karena jumlah SRT yang sangat sedikit. Mereka hanya hidup berdua dengan pasangannya tetapi mereka tetap semangat untuk melakukan pemilahan jika diminta.

Dari 19 responden, sebagian besar $(78,9 \%)$ responden antusias dan besedia melaksanakan pemilahan sampah, dimana kondisi ini bertolak belakang dengan hasil penelitian yang dilakukan oleh Harun [14] dimana di dalam kesimpulannya sebanyak $71 \% \mathrm{KK}$ tidak mendukung terhadap program pemilahan sampah. Di RT04/RW38, hanya 4 responden $(21,1 \%$ ) yang enggan melakukan pemilahan SRT kalau diajak/dilatih karena alasan jumlah SRT yang sangat sedikit, yaitu mereka yang sudah berada pada usia tidak produktif-sebanyak 2 responden, adanya tikus yang akan mengobrak-abrik SRT jika tidak langsung dibuang, dan rasa malas/tidak peduli.

Sebelumnya juga telah disampaikan jika ada beberapa anggota yang telah melakukan pemilahan dan merasakan manfaatnya. Ini adalah potensi dan indikasi yang baik agar penyuluhan tentang pemilahan akan berhasil karena menggunakan anggota Bumdes Sampah sendiri.

\subsection{Analisis Strategi Pengelolaan Sampah dengan SWOT}

Identifikasi faktor internal dan faktor eksternal dalam analisis SWOT dalam pengelolaan timbulan sampah rumah tangga oleh Bumdes Kalurahan Sedangtirto, seperti tabel di bawah ini sebagai acuan menyusun strategi pengelolaan sampah.

Tabel 5 Faktor Internal Pengelolaan Sampah Rumah Tangga (SRT) oleh Bumdes

\begin{tabular}{|c|c|c|c|c|c|c|}
\hline \multirow{2}{*}{ No. } & \multirow{2}{*}{ FAKTOR INTERNAL } & \multicolumn{4}{|c|}{ SKOR } & \multirow{2}{*}{ ANGKA } \\
\hline & & 1 & 2 & 3 & 4 & \\
\hline & KEKUATAN (STRENGTH) & & & & & \\
\hline 1 & Sudah ada Perda Kab. Sleman tentang Pengelolaan & & & & & 4 \\
\hline & Sampah Rumah Tangga Dan Sampah Sejenis & & & & $\sqrt{ }$ & \\
\hline & Sampah Rumah Tangga & & & & & \\
\hline 2 & Adanya pembinaan dari SKPD/Dinas terkait (DLH) & & & $\sqrt{ }$ & & 3 \\
\hline 3 & $\begin{array}{l}\text { Adanya dukungan dari PemDes dalam pengelolaan } \\
\text { SRT }\end{array}$ & & & $\sqrt{ }$ & & 3 \\
\hline 4 & $\begin{array}{l}\text { Adanya dana APBDes untuk persampahan yang bisa } \\
\text { dialokasikan }\end{array}$ & & $\sqrt{ }$ & & & 2 \\
\hline 5 & $\begin{array}{l}\text { Pendapatan retribusi dari persampahan yang bisa } \\
\text { dikembangkan }\end{array}$ & & $\sqrt{ }$ & & & 2 \\
\hline 6 & $\begin{array}{l}\text { Tersedianya sumber - sumber pendanaan potensial } \\
\text { alternatif (pendanaan berbasis masyarakat) yang } \\
\text { berpotensi memfasilitasi dalam mengakses } \\
\text { pendanaan terkait pembangunan sarana persampahan }\end{array}$ & $\sqrt{ }$ & & & & 2 \\
\hline 7 & Ada badan/lembaga Pengelolaan Persampahan & & & & $\sqrt{ }$ & 4 \\
\hline 8 & $\begin{array}{l}\text { Adanya media komunikasi yang bisa digunakan } \\
\text { dalam sosialisasi }\end{array}$ & & & $\sqrt{ }$ & & 3 \\
\hline 9 & $\begin{array}{l}\text { Adanya SDM yang mendukung pengelolaan } \\
\text { persampahan secara mandiri }\end{array}$ & & & $\sqrt{ }$ & & \\
\hline 10 & $\begin{array}{l}\text { Adanya kesadaran masyarakat dalam pengelolaan } \\
\text { SRT }\end{array}$ & & & & $\sqrt{ }$ & 4 \\
\hline 11 & Memiliki alat-alat kerja pengelolaan sampah & & & $\sqrt{ }$ & & 3 \\
\hline 12 & Lokasi pengelolaan terdapat di dalam kalurahan & & & $\sqrt{ }$ & & 3 \\
\hline 13 & Beberapa keluarga mempunyai pekarangan yang luas & & & $\sqrt{ }$ & & 3 \\
\hline 14 & Beberapa keluarga mempunyai ternak dan tanaman & & & $\sqrt{ }$ & & 3 \\
\hline 15 & Lokasi dekat dengan TPST Piyungan & & $\sqrt{ }$ & & & 2 \\
\hline 16 & $\begin{array}{l}\text { Ada beberapa toko yang dapat memanfaatkan } \\
\text { sampah }\end{array}$ & & & $\sqrt{ }$ & & 3 \\
\hline
\end{tabular}


17 Posisi TPS relatif jauh dari pemukiman

18 Lokasi penampung rongok relatif dekat

JUMLAH NILAI KEKUATAN

KELEMAHAN (WEAKNESS)

19 Belum optimalnya dokumen rencana dan strategi pengelolaan persampahan termasuk kelembagaan dan pengaturannya

20 Pembangunan pengelolaan persampahan belum menjadi prioritas Desa

21 Minimnya sistem perencanaan persampahan termasuk database persampahan

22 Belum efektifnya pola pemungutan retribusi sampah yang berjalan selama ini

23 Kemampuan APBDes dalam membiayai pembangunan sanitasi belum optimal

24 Kurangnya pemahaman tentang aspek sanitasi dari Pemerintah Desa

25 Kapasitas prasarana (transferstation) pengelolaan sampah yang belum memadahi

26 Terbatasnya sarana pengelolaan sampah (Bak Sampah 3R, Armada: Gerobak/motor sampah, mesin/alat pengolah sampah)

27 Media yang digunakan untuk sosialisasi dan promosi kurang menarik

28 Kapasitas SDM pengelolaan persampahan masih kurang

29 Pemilahan sampah belum terjadi

30 Belum semua warga kalurahan mengikuti program ini

31 Persepsi masyarakat akan sampah yang negative

32 Lokasi bersebalahan dengan sungai

JUMLAH NILAI KELEMAHAN

\begin{tabular}{|c|c|c|c|c|c|c|}
\hline \multirow{2}{*}{ No. } & \multirow{2}{*}{ FAKTOR EKSTERNAL } & \multicolumn{4}{|c|}{ SKOR } & \multirow{2}{*}{ ANGK } \\
\hline & & 1 & 2 & 3 & 4 & \\
\hline & PELUANG (OPPORTUNITY) & & & & & \\
\hline 1 & $\begin{array}{l}\text { Adanya dukungan dari kelembagaan informal di } \\
\text { masyarakat (PKK, Pengajian, Pos Yandu) sebagai } \\
\text { sarana sosialisasi sanitasi }\end{array}$ & & & & $\sqrt{ }$ & 4 \\
\hline 2 & $\begin{array}{l}\text { Tersedia SKPD (DLH) Pembina kegiatan } \\
\text { pengelolaan sampah }\end{array}$ & & & $\sqrt{ }$ & & 3 \\
\hline 3 & $\begin{array}{l}\text { Adanya peluang pendanaan dari APBDes maupun } \\
\text { APBD Kabupaten }\end{array}$ & & & $\sqrt{ }$ & & 3 \\
\hline 4 & $\begin{array}{l}\text { Adanya program kerjasama dengan pihak swasta } \\
\text { (CSR) }\end{array}$ & & & $\sqrt{ }$ & & 3 \\
\hline 5 & $\begin{array}{l}\text { Sudah ada beberapa pelaku bisnis yang terlibat } \\
\text { dalam layanan sanitasi seperti pengepul dan } \\
\text { pengolah sampah }\end{array}$ & $\sqrt{ }$ & & & & 1 \\
\hline 6 & $\begin{array}{l}\text { Sudah ada inisiatif masyarakat untuk pemasaran daur } \\
\text { ulang sampah walaupun masih terbatas }\end{array}$ & & & $\sqrt{ }$ & & 4 \\
\hline 7 & $\begin{array}{l}\text { Partisipasi masyarakat dalam pemilahan dan } \\
\text { pemanfaatan sampah dari rumah tangga melalui } \\
\text { Bank Sampah maupun secara mandiri }\end{array}$ & & & $\sqrt{ }$ & & 4 \\
\hline 8 & $\begin{array}{l}\text { Ada peluang untuk memanfaatkan lebih banyak } \\
\text { ragam media untuk sosialisasi pentingnya sanitasi }\end{array}$ & & & & $\sqrt{ }$ & 4 \\
\hline
\end{tabular}


yang mudah dan murah (sosial media, pertemuan rutin warga, forum masyarakat, dll.)

9 Adanya kelompok/assosiasi pengelola sampah Mandiri (Jejaring pengelolaan persampahan secara mandiri/JPSM)

10 Gotong royong di masyarakat masih kuat

11 Belum semua warga kalurahan ikut program ini

12 Ada beberapa warga yang mempunyai pengetahuan tentang pengolahan sampah

13 Sebidang tanah kosong di samping TPS bisa dijadikan tempat kompos

14 Tersedia tenaga kerja kasar/harian untuk membantu

15 Harga barang rongsok yang tidak pernah turun

16 Sebagai tempat belajar dan penelitian

JUMLAH NILAI PELUANG

\section{ANCAMAN (THREATS)}

17 Belum optimalnya perluasan, jaringan, aliansi dan kemitraan dari berbagai kelompok sasaran (posyandu, PKK, forum/komunitas masyarakat/paguyuban, JPSM)

18 Belum terbangun sistem informasi sanitasi kota untuk pemangku kepentingan

19 Kesadaran masyarakat untuk membayar retribusi masih rendah

20 Program CSR belum terkoordinasi dengan baik khususnya dalam sektor sanitasi

21 Masih ada masyarakat yang belum terjangkau layanan persampahan

22 Terbatasnya fasilitas pengelolaan sampah (kapasitas transferstation, Ruang pemilah sampah, alat/mesin pengolah sampah)

23 Keterbatasan armada pengangkutan

24 Kesadaran masyarakat masih kurang dalam pengelolaan sampah dan nilai ekonominya

25 Masih banyak masyarakat yang membuang sampah sembarangan

26 Peran swasta masih terbatas untuk pengelolaan persampahan

27 Minimnya pengetahuan masyarakat tentang sanitasi lingkungan

28 Sampah sebagai sumber penyakit dan bau

29 Banjir pada musim penghujan besar/intensif

30 Inefisiensi pengoperasian alat

31 Transfer station penuh SRT

32 Kontaminasi tanah dan air tanah

JUMLAH NILAI ANCAMAN

JUMLAH NILAI PELUANG - JUMLAH NILAI ANCAMAN

Sumber: Data Analisa, 2021

Hasil skoring faktor internal dan eksternal pengelolaan SRT oleh Bumdes Sendangtirto diperoleh hasil total kekuatan (strength): 50, kelemahan (weakness): 45, skor peluang (opportunity): 52 dan ancaman (threats): 54. Sehingga nilai pada faktor internal 5 dan faktor eksternal -2, posisi dari nilai ini jika digambarkan dalam bentuk kuadran sebagai berikut ini. 


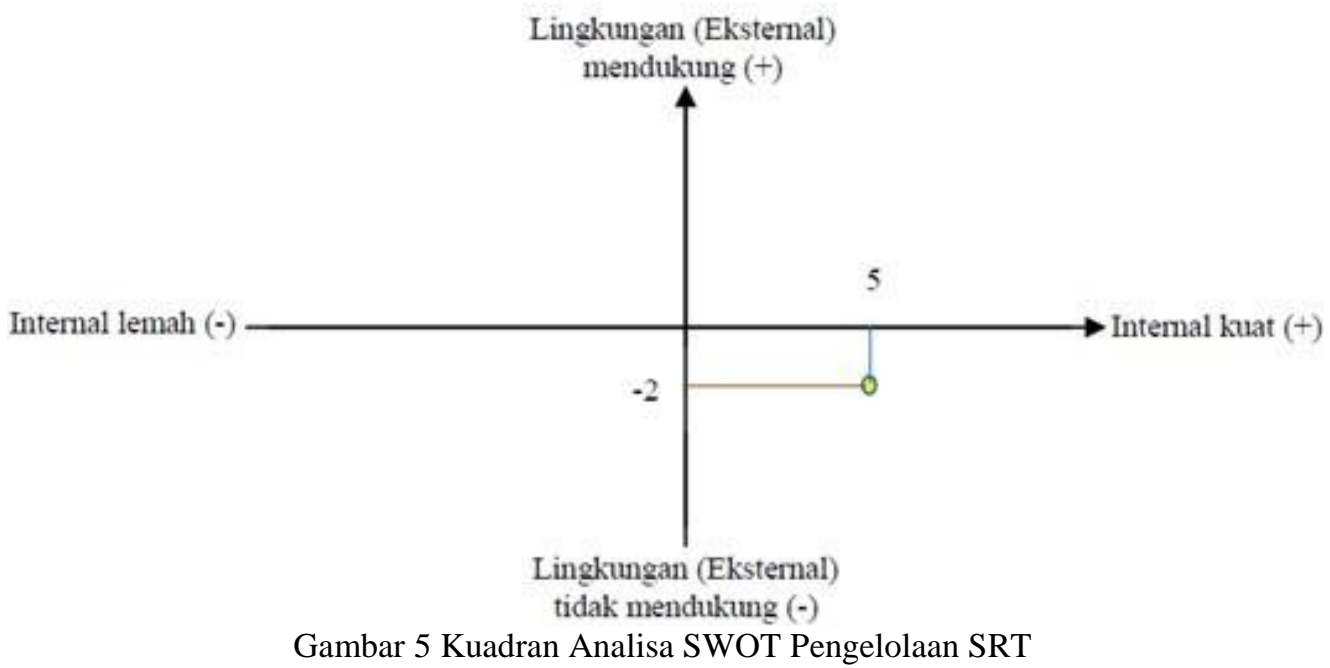

Menurut Rangkuti [2004 dalam 15], analisis SWOT terbagi menjadi empat kuadran utama yang memiliki strategi yang berbeda untuk masing-masing kuadarannya. Keempat kuadran tersebut yaitu strategi agresif (kuadran 1), strategi diversifikasi (kuadran 2), strategi defensive (kuadran 3), strategi turn around (kuadran 4). Berdasarkan Gambar 5, strategi pengelolaan SRT oleh Bumbes Sendangtirto berada pada kuadran 2 sehingga akan mengembangkan Strategi Diversifikasi. Walaupun di Bumber Sendangtirto mengalami berbagai hambatan dalam operasional pengelolaan SRT namun masih mempunyai kekuatan untuk jangka panjang dengan cara diversifikasi dalam pengelolaan SRT antara lain:

1. Mengajak dan memberikan pemahaman semua masyarakat untuk ikut/terlibat dalam pengelolaan sampah 3R dan pentingnya menjaga sanitasi lingkungan yang bersih dan sehat.

2. Menggunakan media-media sosialisasi kepada masyarakat melalui pertemuan forum/paguyuban masyarakat, PKK, dan media sosial untuk kampanye pengelolaan sampah

3. Meningkatkan/menambah kapasitas transferstation

4. Mencari sumber pendanaan dari berbagai pihak dalam pengembangan prasarana dan sarana pengelolaan sampah: CSR, APBDes, Dinas Lingkungan Hidup serta pemangkukepentingan lain dalam penanganan sampah.

5. Mengolah sampah menjadi produk yang mendukung livelihood/kegiatan ekonomi masyarakat seperti kompos untuk mendukung kegiatan pertanian masyarakat, pembuatan Manggot untuk peternakan dan perikanan. Dan pemilahan anorganik tabungan melalui Bank Sampah atau dibuat kerajinan.

Selain kelima strategi diversifikasi di atas untuk pengelolaan sampah secara mandiri dan berkelanjutan Bumdes Sendangtirto harus menjalin komunikasi dengan JPSM Kabupaten/Kota. JPSM merupakan fasilitator pemerintah dan masyarakat serta sebagai agen pemberdayaan melalui pola komunikasi pada level makro dan mikro. JPSM merupakan tempat saling bertukar informasi dan pengalaman dalam penanganan sampah. Hal ini akan meningkatkan kapasitas SDM pengelola sampah dan masyarakat pengelolaan sampah di Sendangtirto.

\section{KESIMPULAN} beberapa hal:

Dari studi pengelolaan dan timbulan sampah di RT04/RW38 Dusun Noyokerten dapat disimpulkan

1. Sebagian besar warga mengaku tidak melakukan pemilahan SRT, walaupun sesungguhnya mereka menggunakan kantong plastik bekas untuk wadah SRT.

2. Potensi menumbuhkembangkan kesadaran akan pemilahan SRT cukup tinggi mengingat ada beberapa warga yang sudah berpengalaman memilah sampah. Untuk ini, mereka nantinya dapat dijadikan narasumber ketika penyuluhan diberikan kepada mereka.

3. Beberapa keluarga mempunyai pekarangan dan binatang piaraan yang dapat dimanfaatkan. Pekarangan dapat dibuat jogangan untuk membuang sampah dan memanfaatkan binatang piaraan untuk memanfaatkan sisa dapur.

4. Sebagian besar mereka setuju untuk melaksanakan pemilahan SRT di rumah.

5. Berdasarkan analisis SWOT pengelolaan sampah rumah tangga di Sendangtirto oleh Bumdes berada pada kuadran 2 sehingga strategi yang cocok digunakan dalam pengelolaan SRT adalah strategi diversifikasi. 
Saran -saran yang dapat diberikan kepada pengurus Bumdes Kalurahan Sendangtirto, adalah:

1. Mengupayakan kampanye dan pendampingan segregasi sampah di rumah tangga dan pengelolaan SRT secara ramah lingkungan seperti pemberian pakan ternak dan pembuatan kompos dari sisa dapur dan pembuatan jogangan bagi mereka yang mempunyai halaman yang cukup.

2. Membuat bank-bank sampah pada level dusun guna menekan timbulan sampah rumah tangga.

3. Dari analisis SWOT diketahui upaya diversifikasi pengelolaan sampah dengan melibatkan para pemangkukepentingan baik dari segi pendanaan, teknologi, dan pasar perlu dilakukan.

\section{UCAPAN TERIMA KASIH}

Penelitian ini dapat berjalan dengan baik atas izin dan dukungan dari Lurah Sendangtirto dan Direktur Bumbes Kalurahan Sendangtirto, Kapenawon Berbah, Kabupaten Sleman, DIY.

\section{DAFTAR PUSTAKA}

[1] Baqiroh, Nur Faizah Al Bahriyatul,“Timbulan Sampah Nasional Capai 64 Juta Ton Per Tahun”, 2019. https://ekonomi.bisnis.com/read/20190221/99/891611/timbulan-sampah-nasional-capai-64-juta-ton-per-tahun, diakses pada 27 September 2020

[2] Sari, P. P., \& Rahardyan, B. , "Identifikasi Faktor-Faktor Yang Mempengaruhi Tingkat Kepercayaan Masyarkat Terhadap Pemilahan Sampah”, Jurnal Teknik Lingkungan, 18(2), 189-200,2018

[3] Noer, B. A., \& Hakim, M. S.,“Social business model untuk pemilahan sampah mandiri di Surabaya”, Paper presented at the Proceeding of Conference on Management and Behavioural Studies, 2016

[4] Kharismawati, Winda, "Evaluasi Dan Perencanaan Aspek Teknis Operasional Pengelolaan Sampah Kabupaten Sleman”, Skripsi, 2018 https://dspace.uii.ac.id/handle/123456789/8258, diakses pada 23 September 2020

[5] National Geographic Indonesia (NGI), "Upaya Pemilahan Sampah di Indonesia Rendah, Ini 3 Faktor Penyebabnya", 2020 https://nationalgeographic.grid.id/read/132135539/upaya-pemilahan-sampah-di-indonesiarendah-ini-3-faktor-penyebabnya?page=all, diakses pada 15 Oktober 2020.

[6] Yudhistirani, S. A., Syaufina, L., \& Mulatsih, S., "Desain sistem pengelolaan sampah melalui pemilahan sampah organik dan anorganik berdasarkan persepsi ibu-ibu rumah tangga", Jurnal Konversi, 4(2), 29-42, 2016

[7] Putra, K. D. I. W., Suryantari, N. L. P. M., Larasati, E., \& Ariana, I. K. A.,"Edukasi Pemilahan Sampah Untuk Menjadikan Masyarakat Mandiri Kelola Sampah Di Desa Kaba-Kaba”, Logista-Jurnal Ilmiah Pengabdian kepada Masyarakat, 4(1), 110-115, 2020

[8] Maulana, R., Pratama, Y., \& Apriyanti, L., "Perencanaan Sistem Pengurangan Sampah Permukiman Bantaran Sungai Cidurian Kota Bandung”, Jurnal Serambi Engineering, 4(2)., 2019

[9] David, Freddy R., "Personal SWOT Analysis", Jakarta: Gramedia Utama, 2015

[10] Rizqi, A., \& Devi, S., "Perilaku masyarakat dalam mengelola sampah rumah tangga di Desa Kemlagi Kecamatan Kemlagi Kabupaten Mojokerto", UIN Sunan Ampel Surabaya, 2019

[11] Ratya, H., \& Herumurti, W., "Timbulan dan Komposisi Sampah Rumah Tangga di Kecamatan Rungkut Surabaya”, Jurnal Teknik ITS, 6(2), C104-C106, 2017

[12] Rahim, I. R., Nakayama, H., \& Shimaoka, T., "Cost analysis of municipal solid waste management in major Indonesian cities”, Journal of Japan Society of Civil Engineers, Ser. G(Environmental Research), 68(6), II_79II_88, 2012

[13] Suhandini, P. ,"Perilaku Masyarakat Terhadap Penggunaan Dan Pelestarian Air Di Lingkungannya (Studi Kasus Di Daerah Aliran Sungai Garang, Semarang)”, Paper presented at the Forum Ilmu Sosial, 2008

[14] Harun, H. , "Gambaran Pengetahuan Dan Perilaku Masyarakat Dalam Proses Pemilahan Sampah Rumah Tangga Di Rw 06 Desa Hegarmanah", Dharmakarya, 6(2), 2017

[15] Mutia Arda, Dewi Andriany, Yayuk Hayulina Manurung, "Analisis SWOT dalam Menentukan Strategi Pengelolaan Sampah Rumah Tangga Kota Medan”, Prosiding Konferensi Nasional Ekonomi Manajemen dan Akuntansi (KNEMA). Universitas Muhamadiyah Sumatera Utara, 2020 